\title{
Cytogenetic Studies of the Somatic and Germ-Line Cells in Sand Rats (Psammomys Obesus)
}

\author{
Pen-Ming L. Ming, and Jacqueline Whang-Peng
}

Department of Pathology, University of Maryland, School of Medicine, Baltimore, Maryland and Human Tumor Cell Biology Branch, National Cancer Institute, Bethesda, Maryland, USA

Summary. The chromosomes in both somatic and germ-line cells of the sand rat (Psammomys obesus) were studied. The diploid number of chromosomes was 48 . The autosomes consisted of 4 pairs of large metacentric chromosomes, 10 pairs of medium to small metacentric and submetacentric chromosomes and 9 pairs of telocentric chromosomes. The $\mathrm{X}$ chromosomes in both sexes were the largest of the entire complement. The $\mathrm{Y}$ chromosome was a mediumsized metacentric chromosome. The two $\mathrm{X}$ chromosomes in the female cells were similar in size and morphology but differed in the DNA replication pattern. Studies of the meiotic chromosomes in the male germ-line cells revealed 23 autosome bivalents and the sex chromosomes either as an $\mathrm{XY}$ bivalent or $\mathrm{X}$ and $\mathrm{Y}$ univalents.

Etude cytogénétique de cellules somatiques et germinales du rat des sables (Psammomys obesus)

Résumé. Les chromosomes des cellules somatiques et germinales ont été étudiés chez le rat des sables (Psammomys obesus). Le nombre diploïde de chromosomes est de 48. Les autosomes consistent en 4 paires de grands chromosomes métacentriques, 10 paires de chromosomes métacentriques et submétacentriques de moyenne ou petite dimension et 9 paires de chromosomes télocentriques. Dans les deux sexes, les chromosomes $\mathrm{X}$ sont les chromosomes les plus grands. Le chromosome Y se compose d'un chromosome métacentrique de grandeur moyenne. Les 2 chromosomes $X$ des cellules féminines se ressemblent quant à leur dimension et morphologie, mais diffèrent en ce qui concerne la réplication de l'ADN. L'étude des chromosomes meïotiques provenant des cellules germinales mâles révèle l'existence de 23 autosomes bivalents et des chromosomes sexuels sous forme de XY bivalents ou de $\mathrm{X}$ et $\mathrm{Y}$ univalents.

Cytogenetische Studien an somatischen Zellen und solchen der Keimzellreihe bei der Sandratte (Psammomys obesus)

Zusammenfassung. - Die Chromosomen von somatischen Zellen und Zellen der Keimzellreihe der Sandratte (Psa:nmomys obesus) wurden untersucht. Die diploide Chromosomenzahl betrug 48. Die Autosomen bestanden aus 4 Paaren großer metazentrischer, 10 Paaren mittlerer bis kleiner metazentrischer und submetazentrischer Chromosomen, und aus 9 Paaren telozentrischer Chromosomen. Bei beiden Geschlechtern waren die XChromosomen die größten des ganzen Chromosomensatzes. Das Y-Chromosom war mittelgroß und metazentrisch. Die zwei X-Chromosomen bei Weibchen waren in bezug auf Größe und Morphologie ähnlich, unterschieden sich aber im DNA-Replikationsmuster. Die Chromosomensätze meiotischer Zellen der männlichen Keimzellreihe enthielten 23 bivalente Autosom-Analoge und die Geschlechtschromosomen waren entweder als ein XY bivalent oder als $\mathrm{X}$ und $\mathrm{Y}$ monovalente vorhanden.

Key-words: Sand rat, Psammomys obesus, meiotic chromosomes, mitotic chromosomes, autoradiography, karyotype, cytogenetics, diabetes.
The Egyptian sand rat (Psammomys obesus nicoli) has, in recent years, become a valuable experimental animal because of its unique characteristic of developing a spontaneous diabetic syndrome when the animal is fed Purina laboratory chow [10, 7]. In order to detect any possible chromosome marker or aberration related to its potential of developing spontaneous diabetes, and to establish a basic chromosome complement of this animal, both mitotic and meiotic chromosomes were studied in detail including the studies of DNA replication patterns using autoradiographic techniques. The results are presented in this report.

\section{Material and Methods}

Five female and six male young sand rats ranging from 2-6 months of age were used. The mitotic chromosome preparations were obtained from cells of both bone marrow and spleen by a direct air-drying technique without prior in-vitro culture or in-vivo colchicine administration as described by Tjio and Whang [12]. A detailed analysis of the chromosomes was made on 50 metaphases and karyotypes were prepared from 10 of these cells, 5 from each sex. The total length and arm lengths of each chromosome in 2 female and 3 male metaphase plates were measured according to the techniques described by Chiarelli [2]. The relative length, the arm ratio and the centromeric index of each chromosome were calculated according to the definitions given by the Denver Conference [3].

For autoradiographic studies, the bone marrow cells from the femurs were cultured at $37^{\circ} \mathrm{C}$ in Eagle's suspension medium containing 1 microCurie of $\mathrm{H}^{3}$ thymidine per ml. of medium for four hours. During the last one hour of incubation, colcemide was added to the cultures at the concentration of 0.2 gamma per $\mathrm{ml}$ medium. Slides were made by the air-drying technique. Kodak A. R. stripping film was attached to these slides which were then exposed in the dark at $4^{\circ} \mathrm{C}$ for 7 days, developed, fixed and stained with Giemsa stain $[5,1]$. The labelled metaphases were analyzed and the patterns of DNA synthesis were studied.

The meiotic chromosome preparations were obtained from the male germ-line cells of the testis by a direct air-drying method described by Hultén et al. [6]. 
Results

The Mitotic Chromosomes : The diploid chomosome number of the sand rat was consistently found to be 48 , both in bone marrow and in spleen cells. The autosomes were divided into 3 morphologic groups according to the position of the centromere. There were 4 pairs of large metacentric chromosomes, 10 pairs of medium to small metacentric and submetacentric chromosomes and 9 pairs of telocentric chromosomes. The autosomes were numbered in order of decreasing size within each morphologic group.

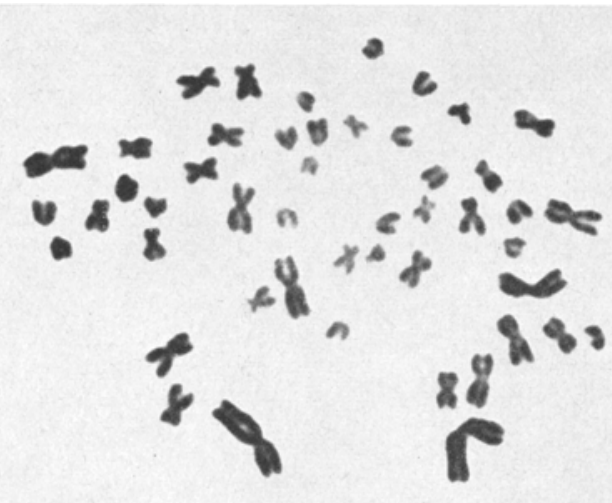

88 $898 x$

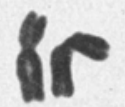

\section{$\begin{array}{lllll}X 8 & 88 & 88 \times 8 \times 8\end{array}$}

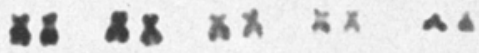

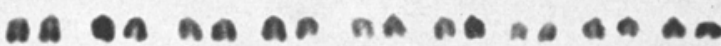

Fig. 1. Metaphase and karyotype of female bone marrow cell. The $\mathrm{X}$ chromosomes are at the right upper corner

The $\mathrm{X}$ chromosomes in both sexes were easily identified as the largest chromsomes of the entire complement. It was a metacentric chromosome constituting $12.07 \%$ (range $11.30-12.68 \%$ ) of the total haploid length. The two $\mathrm{X}$ chromosomes in female cells are similar in size and morphology (Fig. 1). The $Y$ chromosome was the smallest of the large metacentric group constituting 5.72\% (ragne 5.57-5.92\%) of the length of a haploid set. It was invariably much smaller than the $X$-chromosomes, and no satellites have been observed on the $Y$ chromosome (Fig. 2).

The average value of the relative length, the arm ratio and the centromeric index of the mitotic chro- mosomes from five cells are shown in the Table. On the basis of these data an idiogram of the sand rat was constructed (Fig. 3).

The Autoradiographic Studies: In the female, among 200 consecutive metaphases, 96 (48\%) were labelled after four-hour continuous labelling. One of
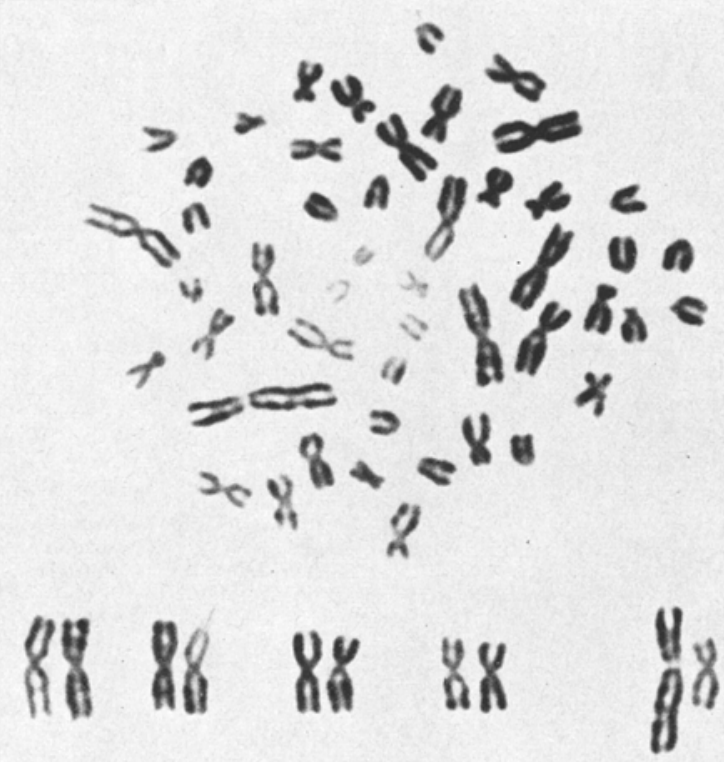

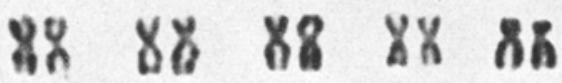

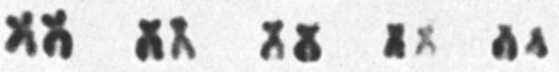

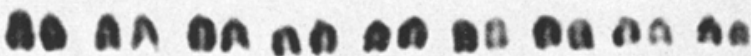

Fig. 2. Metaphase and karyotype of male bone marrow cell. The XY chromosomes are at the right upper corner
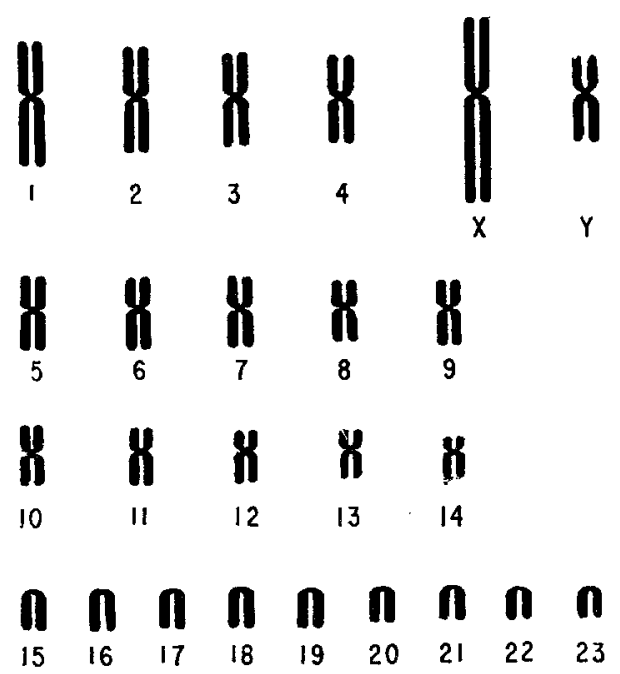

Fig. 3. Idiogram of the sand rat 
the $\mathrm{X}$ chromosomes was consistently found to be the late replicating chromosome of the entire complement. Asynchronism of DNA synthesis is also noted among the autosomes (Fig. 4).

The Meiotic Chromosomes: The chromosomes of the male germ-line cells in various stages of meiosis are shown in Fig. 5. The diploid chromosome number was confirmed by the presence of 48 chromosomes in the 5e). There was no evidence of chiasma formation. Less frequently, $\mathrm{X}$ and $\mathrm{Y}$ were separated as univalents. The chiasma formation was demonstrable in the autosomal bivalents especially the larger ones during early diakinesis. No quadrivalents were observed. The $\mathrm{X}$ chromosome, being the largest, was easily recognized in the second metaphase, while the $\mathrm{Y}$ chromosome could not be identified with certainty. A few polypoid

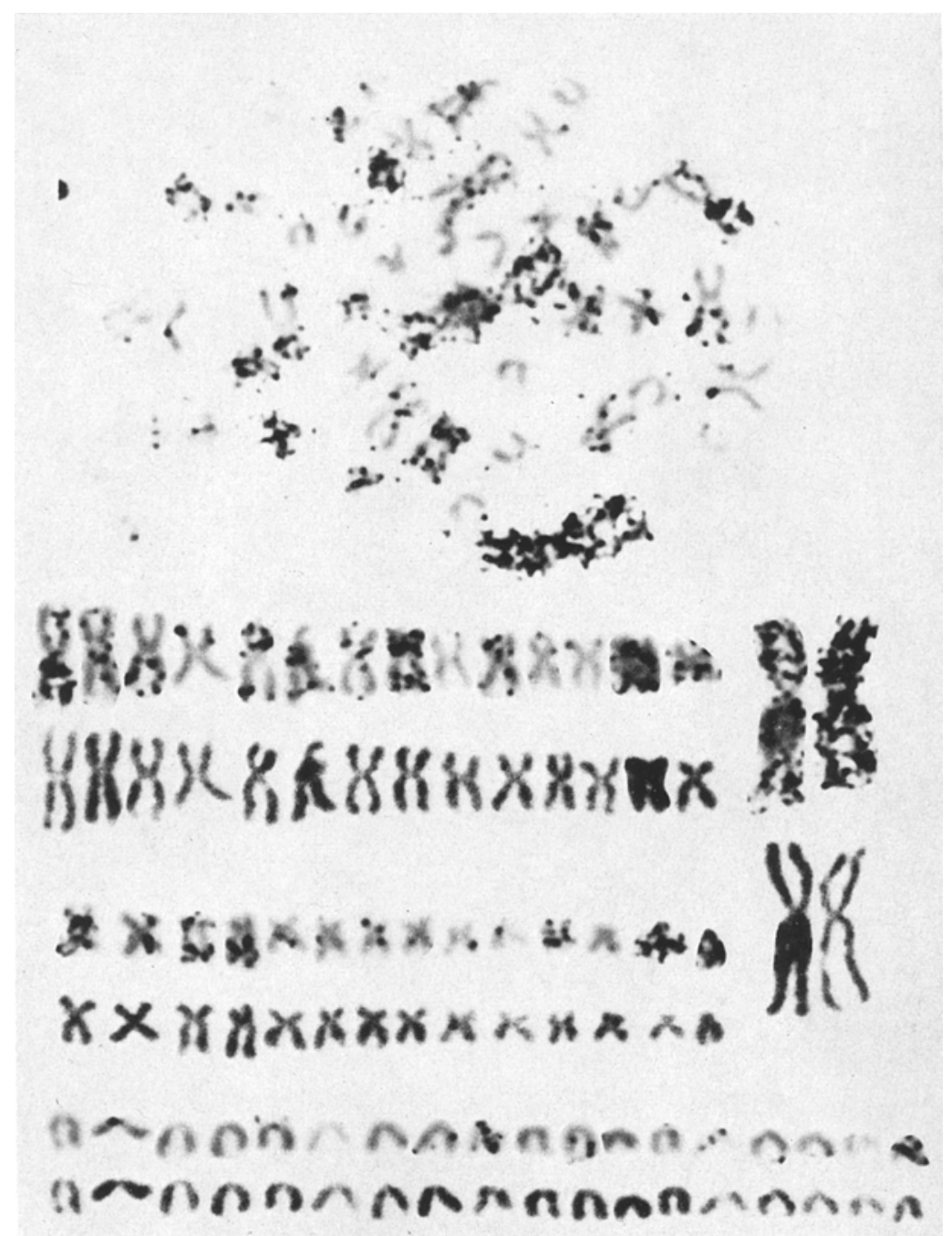

Fig. 4. Autoradiograph and karyotype of female bone marrow cell. The late replicating chromosome is one of the X chromosomes

spermatogonial metaphase, 24 bivalents in diakinesis and first metophase and 24 chromosomes in second metaphase. The sex vesicle was visible in some of the early prophases during the first meiosis. The $\mathrm{X}-\mathrm{Y}$ bivalent was best identified in diakinesis and first metaphase and was the longest among the bivalents. It appeared that the $\mathrm{X}$ chromosome was terminally associated with the short arm of the $X$ chromosome (Fig. cells were found in spermatogonial metaphase and in diakinesis.

\section{Discussion}

The diploid number of the sand rat determined in this study is in agreement with that reported by Smith et al. [11], i. e. $2 \mathrm{~N}=48$. However, the karyo- 


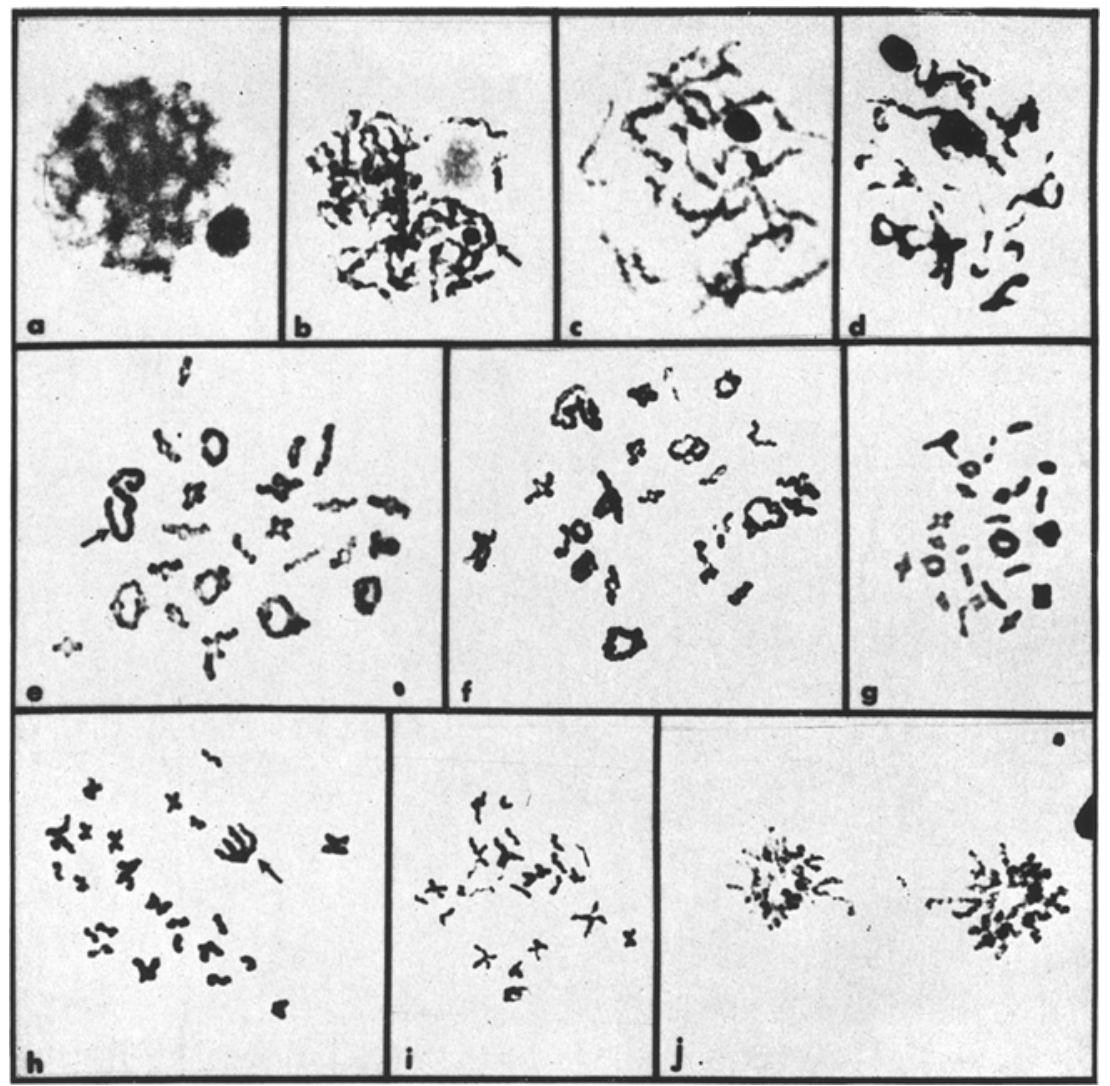

Fig. 5. Male germ-line cells in various stages of meiosis:

a. Leptotone.

b. Zygotene. Arrow indicates sex vesicle.

c. Pachytene.

d. Diplotene. Arrow indicates sex vesicle.

e, f. Diakinesis. 24 bivalents. Arrow points to the $X Y$ bivalent with terminal association.

g. First metaphase.

h. Second metaphase. The X chromosome is indicated by arrow.

i. Secondmetaphase. No X chromosome. The $\mathrm{Y}$ chromosome can not be identified with certainty.

j. Second anaphase-telophase.
Table. Quantitative characteristics of the sand rat chromosomes

Average value of 2 female and 3 male metaphases

\begin{tabular}{llll}
\hline $\begin{array}{l}\text { Chromo- } \\
\text { some } \\
\text { No. }\end{array}$ & $\begin{array}{l}\text { Relative } \\
\text { length } \pm \text { SD }^{\mathrm{a}}\end{array}$ & $\begin{array}{l}\text { Arm } \\
\text { ratio }\end{array}$ & $\begin{array}{l}\text { Centro- } \\
\text { meric } \\
\text { index }\end{array}$ \\
\hline 1 & $85.79 \pm 4.23$ & 1.20 & 45 \\
2 & $72.82 \pm 3.25$ & 1.11 & 47 \\
3 & $65.68 \pm 1.48$ & 1.22 & 45 \\
4 & $59.51 \pm 2.59$ & 1.24 & 45 \\
5 & $48.52 \pm 4.79$ & 1.25 & 44 \\
6 & $46.91 \pm 4.50$ & 1.21 & 45 \\
7 & $45.35 \pm 2.34$ & 1.21 & 45 \\
8 & $41.79 \pm 1.48$ & 1.29 & 44 \\
9 & $41.40 \pm 1.65$ & 1.70 & 37 \\
10 & $37.29 \pm 1.93$ & 1.59 & 38 \\
11 & $33.58 \pm 1.49$ & 1.62 & 38 \\
12 & $31.62 \pm 2.49$ & 1.64 & 38 \\
13 & $28.83 \pm 2.81$ & 1.51 & 40 \\
14 & $25.85 \pm 2.22$ & 2.21 & 31 \\
15 & $28.04 \pm 3.01$ & $\infty$ & 0 \\
16 & $27.12 \pm 2.19$ & $\infty$ & 0 \\
17 & $25.40 \pm 2.33$ & $\infty$ & 0 \\
18 & $24.95 \pm 1.50$ & $\infty$ & 0 \\
19 & $23.87 \pm 2.19$ & $\infty$ & 0 \\
20 & $23.22 \pm 2.58$ & $\infty$ & 0 \\
21 & $21.56 \pm 1.76$ & $\infty$ & 0 \\
22 & $20.13 \pm 3.08$ & $\infty$ & 0 \\
23 & $19.67 \pm 2.16$ & $\infty$ & 0 \\
$X$ & $120.72 \pm 5.08$ & 1.47 & 40 \\
$Y$ & $57.20 \pm 2.45$ & 1.44 & 41 \\
\hline
\end{tabular}

a Standard Deviation. typic arrangements of the chromosomes are quite different. In our study, the autosomes consist of 3 morphological groups : 4 pairs of large metacentric, 10 pairs of medium to small metacentric and submetacentric and 9 pairs of telocentric chromosomes. The X chromosomes in both female and male are the largest in the entire complement with two $\mathrm{X}$ chromosomes of similar size in the female. This is in contrast to the observations of Smith who found the $\mathrm{X}$ chromosomes to be medium-sized metacentric and the second $X$ chromosome in the female smaller than the first $\mathrm{X}$ or the $\mathrm{Y}$ chromosome. The identification of $\mathrm{X}$-chromosome in our experiment is supported by the autoradiographic studies which reveal one of the $X$ chromosomes in the female being late replicating. The DNA replication pattern is in keeping with many species of mammals [9] including man [4]. Furthermore, in the male cells, a conspicuouly large unpaired chromosome is consistently present, and in diakinesis, an especially long XY bivalent is noted.

Specific chromosome aberrations have not been found in man with diabetes mellitus [8] or in animals which have tendency to develop spontaneous diabetes [11]. The present study shows that there are no specific chromosome features which may be related to the development of spontaneous diabetes in the sand rat.

Acknowledgements: The authors express their thanks to Mrs. Grazina Pearson and Mrs. Turid Knutsen for 
technical assistance and to Dr. Arthur A. Like, Harvard Medical School and Dr. Bernard Brodoff of New York Medical College for supplying the sand rats used in this study.

Supported in part by United Staates Public Health Service Grant No. HE-06370.

\section{References}

1. Binachi, N., Lima-De-Faria, A., Jaworska, H.: A technique for removing silver grains and gelatin from tritium autoradiographs of human chromosomes. Hereditas 51, 207-211 (1966).

2. Charelli, B.: Comparative morphometric analysis of the primate chromosomes. I. The chromosomes of the Anthrapoid apes and of man. Cytologia 15, 99-121 (1962).

3. Denver Conference: A proposed standard system of nomenclature of human mitotic chromosomes. Ann. hum. Genet. 24, 319-325 (1960).

4. German, J.L.: DNA synthesis in human chromosomes. Trans. N.Y. Acad. Sci. 24, 395-407 (1962).

5. Gude, W.D., Upton, A.C., Odell, T.T., Jr.: Giemsa staining of autoradiograms prepared with stripping film. Stain Technol. 30, $161-162$ (1955).
6. Hultén, M., Lindsten, J., Ming, P.L., Fraccaro, M.: The $X Y$ bivalent in human male meiosis. Ann. hum. Genet. (London) 30, 119-123 (1966).

7. Miki, E., Like, A.A., Soeldner, J.S., Steinke, J., Cahill, G.F., Jr.: Acute ketotic-type diabetic syndrome in sand rats (Psammomys obesus) with special reference to the pancreas. Metabolism 15, $749-760$ (1966).

8. Ming, P.L., Cervantes-Amezcus, A., Camarini, R.S. Chromosome studies in patients with diabetes mellitus. JAMA 194, 551 (1965).

9. Mittwoch, U.: Sex chromosomes, pp. 207-208. New York: Academic Press. 1967.

10. Schmidt-Nielsen, K., Haines, H.B., Hackel, D.B. Diabetes mellitus in the sand rat induced by standard laboratory diets. Seience 143, $689-690$ (1964).

11. Smith, A.G., Hackel, D.B., Schmidt-Nielsen, K. Chromosomes of the sand rat (Psammomys obesus). Can. J. Genet. Cytol. 8, 756-758 (1966)

12. Tjio, J.H., Whang, J.: Chromosome preparations of bone marrow cells without prior in vitro culture or in vivo colchicine administration. Stain Technol. 37, $17-20(1962)$.

Pen-Ming L. Ming

Department of Pathology

University of Maryland

School of Medicine

Baltimore, Maryland, USA 